UDC 620.191:620.179.16

\title{
ミガキ帯鋼表面キズの超音波自動挆傷法
}

\author{
加 藤 哲 男*, 中 瀬 久 生**
}

\section{Ultrasonic Inspection of Surface Defects on Cold Rolled Steel Strip}

\author{
Tetuo Katô, Hisao Nakase
}

\begin{abstract}
Synopsis
Utilizing of ultrasonic method was studied for inspecting of surface defects on cold rolled steel strip.

When the ultrasonic wave is projected in the water against surface of steel strip keeping proper projecting angle, the total reflection occures on the surface.

But there occurs irregular reflection on parts where there are any defects or flaws and detecting of such defects is possible through receiving the reflection.

Specimens with artificial flaws were used for the test concerning the correlation between the shape of probe, projecting condition and flaws. Furthermore, the test was also made for defecting of some natural flaws.

All fine defects visually inspected could be detected and it was confirmed that the method was capable enough of practical use.
\end{abstract}

\section{1. 緒宣}

ミガキ帯鋼の表面キズの㭘查は，現在ほとんど目視 で行なわれているが，多くの工数を要し，しかす微細 なキズを発見することがかなり困難であって，検査工 の努力に負 らところが少なくない。個人差も多く,や やすすると見逃しす避けられない状態である。これに 対する自動化は業界の重要な課題となっている。

これに対して，適用する非破壇挨査の方法として各 方面において種々の方法が検討され，光の利用も行な われてきているよ5である。しかし，微細なキズの检 出精度に関しては，超音波を利用するのが有利である

昭和 46 年 8 月 31 日受付

* 大同製䤱侏研究開発本部中央研究所, 工博

**大同製鋼侏研究開発本部中央研究所
と考えられる。鏡面に光を斜めに入射すると，四凸の ある部分についてのみ乱反射か生ずるが，これと同様 にミガキ带鋼の表面に適当な角度で超音波を入射する と,キズの部分で乱反射の生ずることが予想される。 この乱反射される超音波を受信することにより表面キ ズの换出を行なえば，省力，自動化に結びつけること が可能であると推定される。

このよ5な発想にもとずき，これまで実験室的に水 浸法により各種の検討を重ねてきた。実用化の可能性 が明らかになってきているのでここに実験結果をと りまとめて報告する。

\section{2. 試匰方法および被試䀫材}

試験方法の概略を Fig.1 に示す。被試験材は水中 に配置する。いま探触子より超音波を水を介して被試 験材に入射すると表面で射または屈折を起こす。こ 


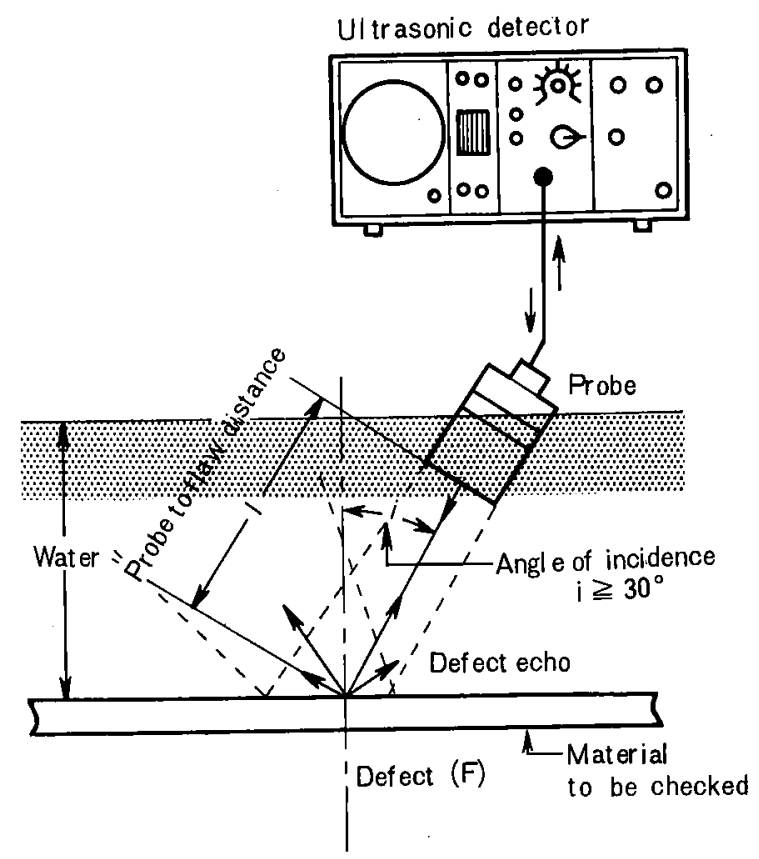

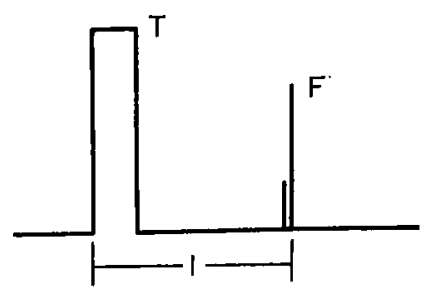

Wave shape on CRT When ther'e are defects

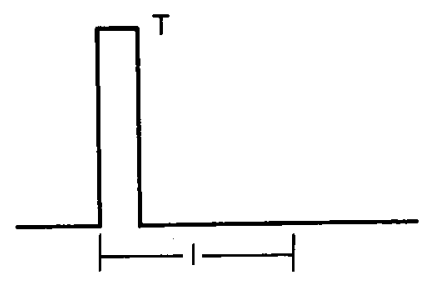

Wave shape on CRT When there are no defects

Fig.1. Explanation of surface defect detecting method by immersion ultrasonic wave.

の場合，超音波が風折するときは一部の反射が探触子 にもどることが予想されるが，完全に全反射する場合 にはその反射波は探触子にもどらない。しかし，全反 射の場合, 表面にキズが存在するとキズの位置で乱反 射が生じ，そのため反射波が探触子に受信されて，超 音波探傷器のブラゥン管上で観測されるようになる。 これらの波形観測の状況は図中右方に示した。

Fig. 2 飞抹いて, I の物質の音速を $C_{D}, \mathbb{I}$ の物質 の音速を $C_{S}$ とすると，Iおよび境界に批て入

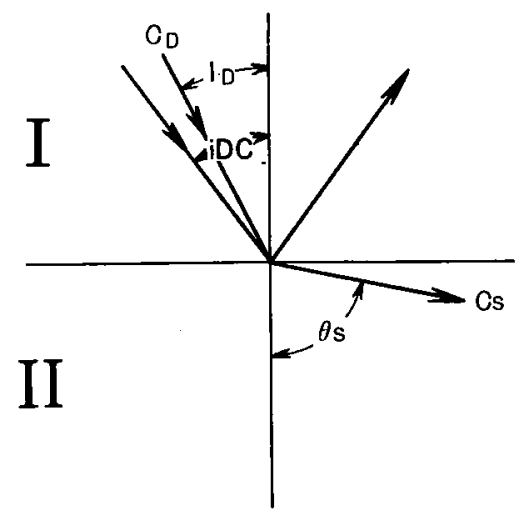

Fig.2. Principle of through and reflection.
射角 $i_{D}$ と屈折角 $\theta_{S}$ とのあいたに次の関係が知られ る。

$$
\frac{C_{D}}{\sin i_{D}}=\frac{C_{S}}{\sin \theta_{S}}
$$

これについいて，超音波が被試験材に入らず表面で 全反射する条件は $\theta_{S}>90^{\circ}$ であるから I の物質, 水 の音速 $C_{D}=1500 \mathrm{~m} / \mathrm{sec}, \mathbb{I}$ の物質, 鋼の横波の音速 $C_{S}=3200 \mathrm{~m} / \mathrm{sec}$ から臨界の入射角 $i D C$ を求めると

$$
\begin{aligned}
i_{D C}= & \frac{C_{D} \cdot \sin \theta_{\mathrm{S}}}{C_{S}}-\frac{1500 \times 10^{5} \times 1}{3200 \times 10^{5}} \div 0.47 \\
& \doteqdot \sin 28^{\circ}
\end{aligned}
$$

となる。入射角は約 $30^{\circ}$ 以上にとれば完全に全反射す ることがわかる。

本試験方法では, この水中に打ける全反射の条件に おいて，表面キズで生ずる乱反射の超音波を観察する ことによりキマ゙検出を行なら。

試験には, 東京計器製のスペリー式, UM721 型超 音波探傷器を使用した。入射角を正確に求めるため, 回転角度設定精度 $\frac{1}{100}$ 度の保持具を製作して用いた。

探触子は Table 1 に示すごとき丸形, 角型拉よび 長方形のP Z TおよびL H振動子のものについてそれ ぞれ比較試験を行ない，ついでキズの状態の影響につ いて調べた。

被試験材としては，はじめミガキ带鎘の表面に放電 
Table 1. Probe iused in test.

\begin{tabular}{|l|c|c|c|c|c|}
\hline \multicolumn{1}{|c|}{ Name } & $\begin{array}{c}\text { Material } \\
\text { duality }\end{array}$ & Frequency & Size $(\mathrm{mm})$ & $\begin{array}{c}\text { Shape of } \\
\text { Transducer }\end{array}$ & Remark \\
\hline $5 Z 20 \mathrm{I}-\mathrm{N}$ & ${ }^{*} \mathrm{PZT}$ & $5[\mathrm{MHz}]$ & $20 \phi$ & Round & *PZT means Zircon \\
$2.25 Z 20 \mathrm{I}-\mathrm{N}$ & $\mathrm{PZT}$ & 2.25 & $20 \phi$ & 1 & Titan acid zinc ma- \\
$5 \mathrm{~L} 20 \mathrm{I}-\mathrm{N}$ & ${ }^{*} \mathrm{LH}$ & 5 & $20 \phi$ & $*$ & gnetic vessel \\
$2.25 \mathrm{~L} 20 \mathrm{I}-\mathrm{N}$ & $\mathrm{LH}$ & 2.25 & $20 \phi$ & $"$ & ${ }^{* *}$ LH means sulfu- \\
$2.25 Z 10 \times 20 \mathrm{I}-\mathrm{N}$ & $\mathrm{PZT}$ & 2.25 & $10 \times 20$ & Rquare & ric acid Lithium \\
$2.25 Z 10 \times 60 \mathrm{I}-\mathrm{N}$ & $\mathrm{PZT}$ & 2.25 & $10 \times 60$ & Rectangular & \\
\hline
\end{tabular}

加工により種々の深さの線状キズをつけて，人エキズ 試片を作成し，それについて試験を行なった。ついで カキキズ，スケールキズ，飛び込みキズ，八ガレ，肌 フレなど数種の自然キズについても試験を行なった。

\section{3. 人エキズによる探鹪試験結果}

はじめに，無キズのミガキ带鋼表面に放電加工によ り作った幅 $0.3 \mathrm{~mm}$, 深さ $0.01 \mathrm{~mm}$ の線状キズについて 超音波入射角, 探触子形状打よび探触子の影響につい て調べる実験を行なった。

Fig. 3 は，超音波の入射角と人工キズからの反射 エコー高さの関係について測定した結果である。たて

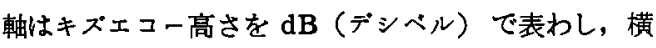
軹は入射角で $5^{\circ}$ おきに $30^{\circ}$ から $50^{\circ}$ までとってある。

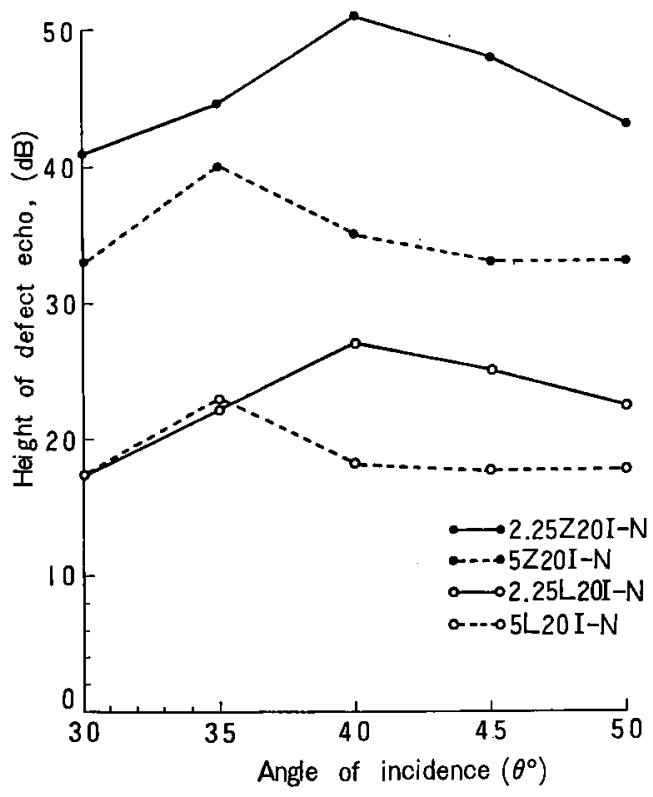

Fig. 3. Correlationship between angle of incidence and height of defect echo.
用いた探触子はすへて $20 \mathrm{~mm}$ て周波数は $5 \mathrm{MHz}_{2}$ と2. 25 $\mathrm{MHz}_{z}$ の 2 種類とし, さらに振動子の材質はそれぞれ $\mathrm{PZT}$ と L Hの 2 種類である。

図中，入射角は $35^{\circ}$ ないし $40^{\circ}$ に拟いて最も高い感 度となるェュー高さの変化を示している。探伤周波数

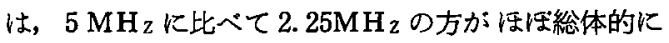
高い感度を示し, また，振動子の材質はL Hに比へて PZTの方がるかに高い感度を示した。

この結果から周波数を $2.25 \mathrm{MHz}$ に選定して, さら に探触子の形状の影響を調べこととし，直径 $20 \mathrm{~mm}$ の丸形, $10 \times 20 \mathrm{~mm}$ の角形および $10 \times 60 \mathrm{~mm}$ の長方形の 3 種類の形の P Z T 探触子について, それぞれ入射角 と人エキズからの反射ェュー高ざを測定した。

キズに対する探触子の配置は図中に示したごとく， 丸形探触子についてはその直径に相当する位置, 角形 および長方形探触子については，その中央部の短辺方 向になる位置とした。その結果を Fig. 4 に示す。探 傷面積の関係での相対的キズェコー高さに差はある が, 入射角に対してほ济同㑯向の变化を示し，約 $40^{\circ}$ のところで最む高い感度となっている。

Fig. 5 は，前記までの試験と同様の条件で入射角 $40^{\circ}$ にセットし，探触子を線状キズに対して直角方向 に移動させ，相対位置を変えて探傷範囲を求める試験 を行なった結果である。たて軸にキズからの反射エコ 一高さをとり，横軸に探傷範囲をとって示した。丸形 探触子はエコー高さは高くなっているが範囲は狭く局 がだれている。角形探触子になると両肩がもりあがる よ5な形になり，探触子の幅が同一寸法であるにもか かわらす探賃範囲が増加する。これが長方形探触子に なると，長辺の増加にともなってそのまま探傷範囲の 増加になっている。

実用上広い幅の板材の探伤には長方形探触子が適し ていると考党る。しかし，この場合実用にあたっては 探触子の設計と製造に当り，さらに探賃範囲の全体に わたり感度が均一となるごとき配虑が大切である。 


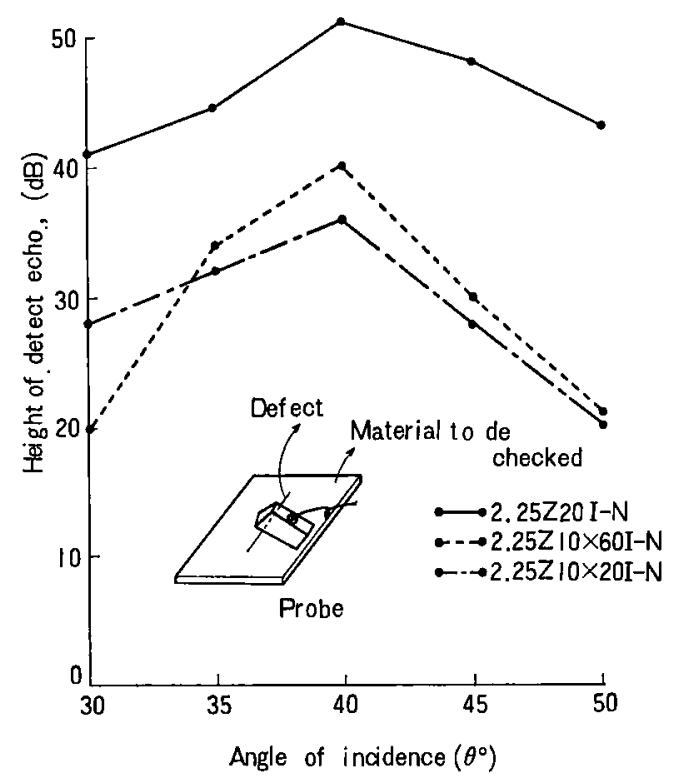

Fig. 4. Correlationship between change of probe shape and height of defect echo.

以上の試験結果により, 以後の人工キズによる試験 はすべて長方形探触子を使用し, 周波数 $2.25 \mathrm{MHz}$,

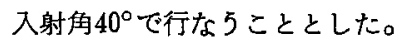

Fig. 6 は, 板幅 $90 \mathrm{~mm}$, 厚さ $0.6 \mathrm{~mm}$, 長さ $4 \mathrm{~m}$ の ミガキ带鉵に写真および図に示したごとく長さ約 500 mmで各種の幅および梁さに作った線状キズについて，

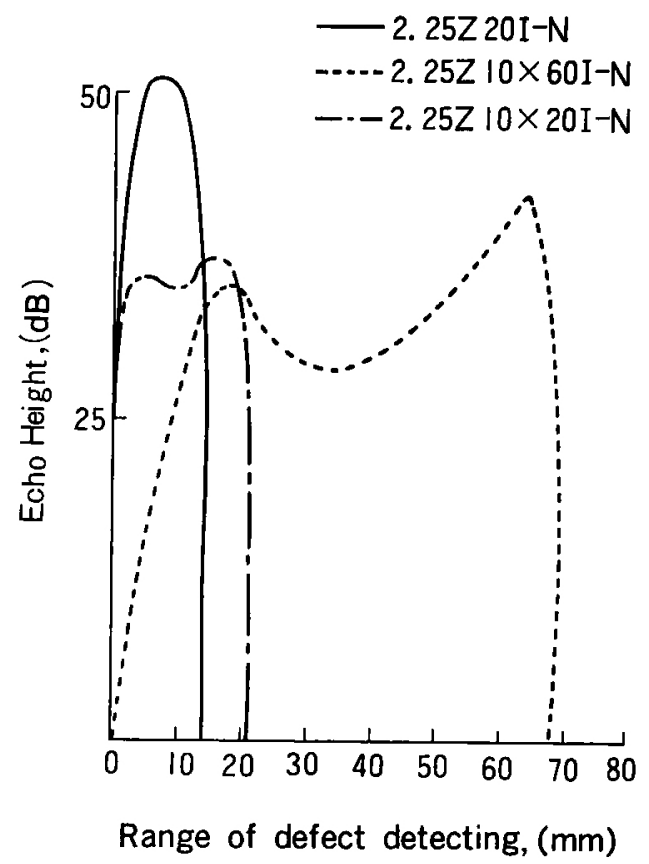

Fig. 5. Range of defect detecting in three probes.

探触子の下で供試材を移動させて連続的に測定した結 果を示した。探賃感度は幅 $0.3 \mathrm{~mm}$, 深さ $0.01 \mathrm{~mm}$ の人 エキズ試片でのエコー高さを $100 \%$ に合わせて行なっ た。キズの大きさは探賃後周国を削って測定したるの であるが，椧出した波形の高さとキズの大きさとの間 に良い対応が認められる。

Fig. 7 は, 同様にして写真执よび図のごとく線状
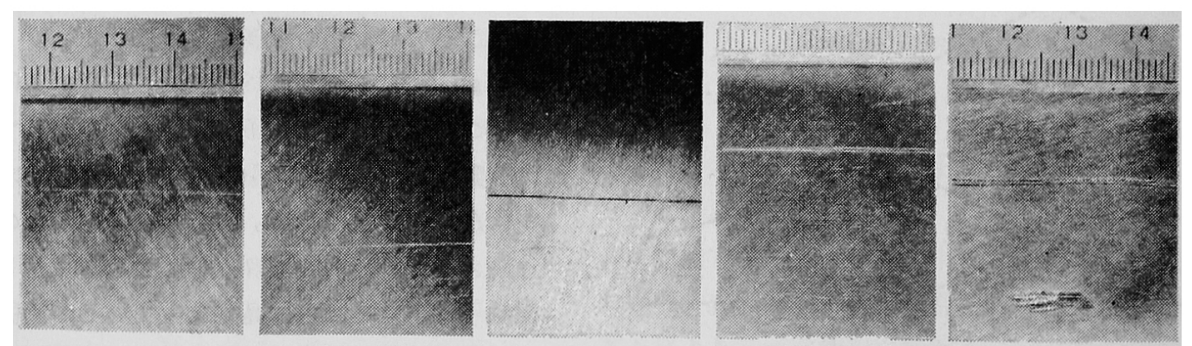

Shape of artifial defects

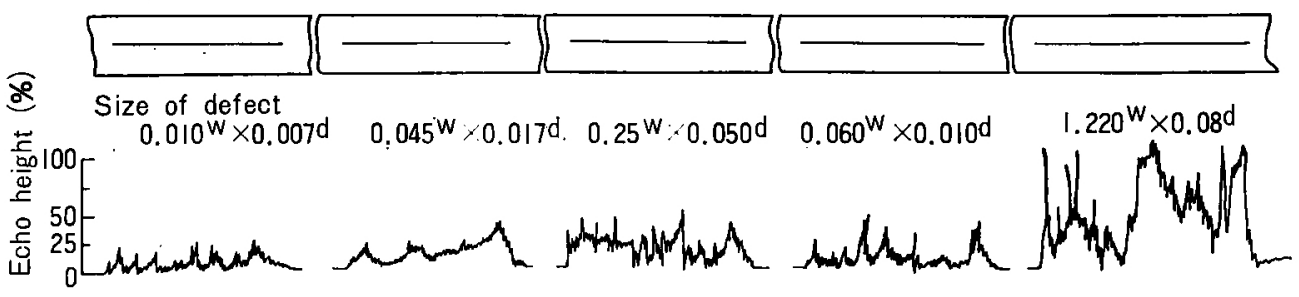

Fig. 6. Test results for test piece 1 of actificial defects. 


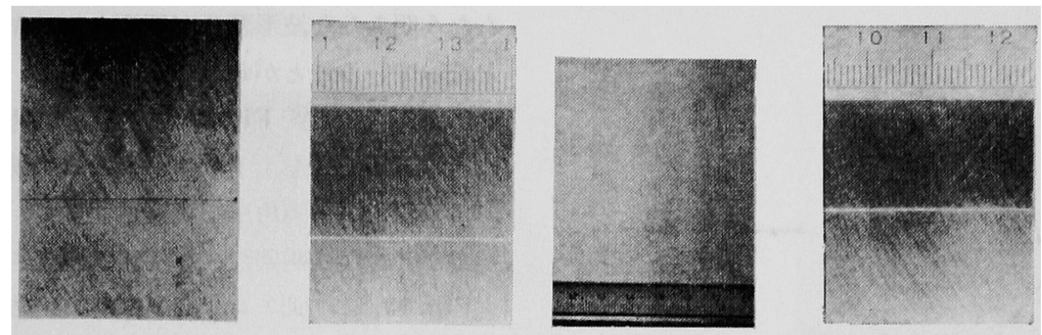

Shape of artificial defects

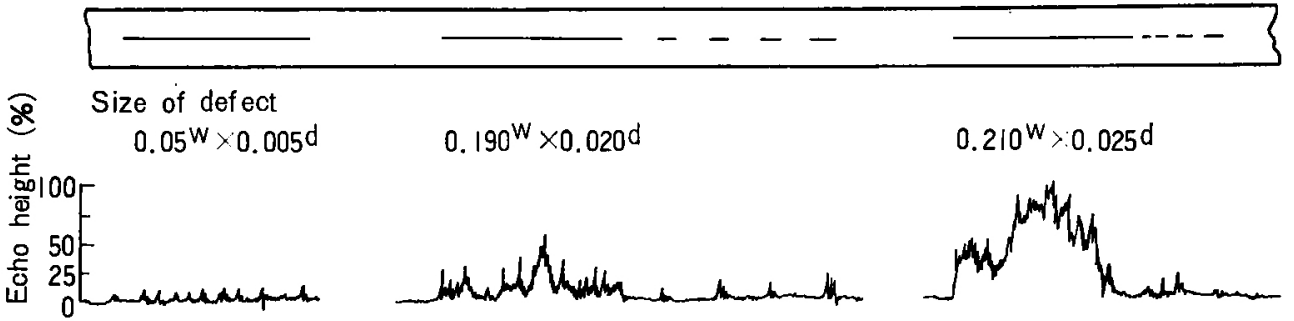

Fig. 7. Test results for test piece 2 of artificial defects.

キズとともに長さ $5 \mathrm{~mm}$ 程度の点状キズを作った人工 キズ試片で，前と同一条件で探賃した結果を示す。点 状キズす検出し，波形の幅がキズ状態と良く対応して いることが認められる。

Fig. 8 は以上のごとき実験から線状キズの大きさ （深さ）とエコー高さの関係を求めた結果を示した。 人工キズの大きさとキズェコー高さは恬は直線的な相

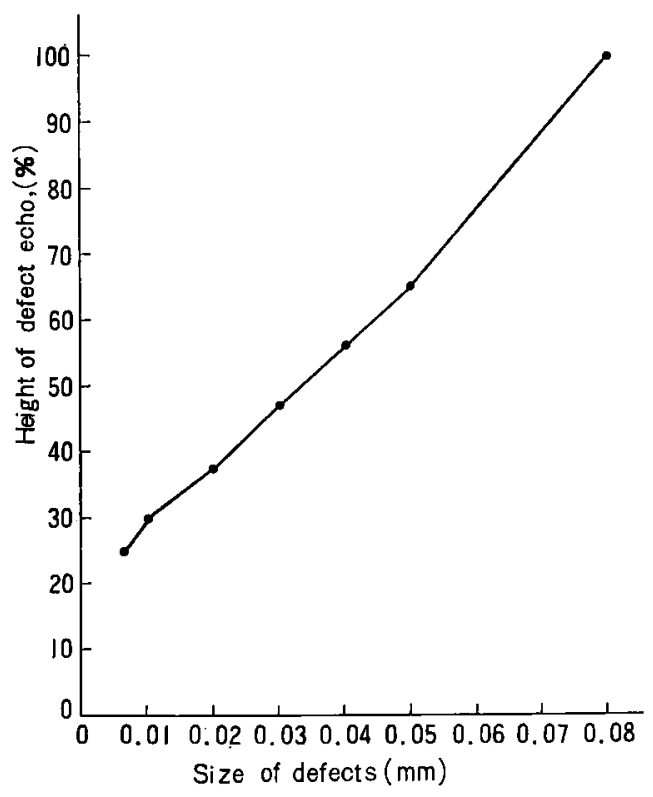

Fig. 8. Correlationship between size of artifcical defect and height of defect echo.
関関係を示し，良く比例していることが認められる。

\section{4. 自然キススによる探甥試験結果}

人工キズによる試験結果から探賃の可能性が把幄さ れ探賃条件す明らかとなったので，続いて各種自然キ ズによる探伤試験を行ならこととした。辰期にわたり 工程中にある材料の中から各種のキズ 試料を採取し た。

探触子は, 周波数 $2.25 \mathrm{MHz}$ で長方形の P Z Tを使 した。

Fig. 9 は，カキキズ，飛び込みキズ，およびスケ ールキズの3 種類のキズについて, 入射角とエコー高 さの関倸について求めた結果を示す。カキキズについ ては，入射角 $37^{\circ}$ 付近にェコー高さの最大がみられ る。飛び込みキズについては，320 付近にェコー高さ の最大がみられる。これらに対し，スケールキズでは はじめ入射角とともにェコー高さが减少しこのよ5な 変化は認められない。

さきの人エキズにおける試験の結果から見るとこれ らのキズの種類により，入射角とエコー高さの関係の 推移に大幅の変化が認められた。これについては，人 工キズは鋭角なキズロ形状となっているのに対し，カ キキズおよび飛び込みキズではそれぞれ漸次キズロが 鈍角に広がっていることによるものと考光られる。ス ケールキズではそれがさらに広がって明確な凹円を示 さなくなったことによるものと考えられる。

この現象については，まず形状に応じ通常の水浸探 


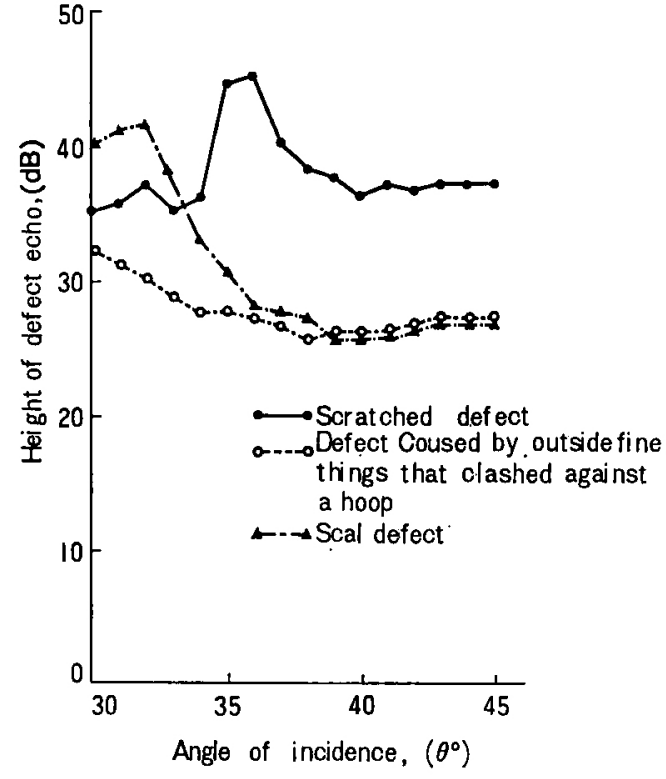

Fig. 9. Correlationship between kind of natural defects and height of defect echo.

賃がみられるごとき反射波（（波）関与するよになっ ていることが推定される。そのため, 安定な感度の探 偒を行ならためには， S 波の影響を避けることが必要 であるという観点から, 以後の自然キズの探伤は, 入 射角 $45^{\circ}$ で行ならこととした。

Fig.10は, 前記 3 種類のキズについて連続探賃試 験を行なった結果を示した。いずれも試料の移動にと
あなう明らかな波形変化が観測され，キズ㭘出が可能 となっていることがわかる。

Fig.11 および Fig.12 は，各種状態のハガレキズ の探伤試験結果を示ず。八ガレキズの場合は，キズロ 形状は鋭角から鈍角まで複雑となっているが，試料の 移動にとむな5 明確な波形変化が観測された。

Fig.13は, 肌アレ状態の探伤試験結果を示す。試 料の移動にともなって細かい波形変化が観測された。

このほか，目で見られるキズについては微細なもの でもすへてここの方法で検出することができた。

\section{5. 結}

ミガキ帯鋼の表面キズの検査に, 超音波を利用する 方法について調查研究を行なった。

このキズ㭘出法は，水中での斜め入射による全反射 の状態に批いて，キズ部分で発生する乱反射を受信す るという新しい考案にもとずくあのであるが，ミガキ 帯鋼表面キズの探偒法として十分探傷可能である。

はじめ，人工の線状キズに対して各種探賃条件を求 める実験を行ない，その結果にもとずいて各種の自然 キズを検查する実験を行なって，探傷条件を確立し た。

これにより目視しうるキズはすべて検出可能である ことを確諗することができた。

この方法により，ミガキ带銅の表面キズ探賃の自動 化も可能であると判断することができる。

本研究にあたり，試料および実験に協力された，大 同製銅林王子工場の桑原嘉男君に感謝します。

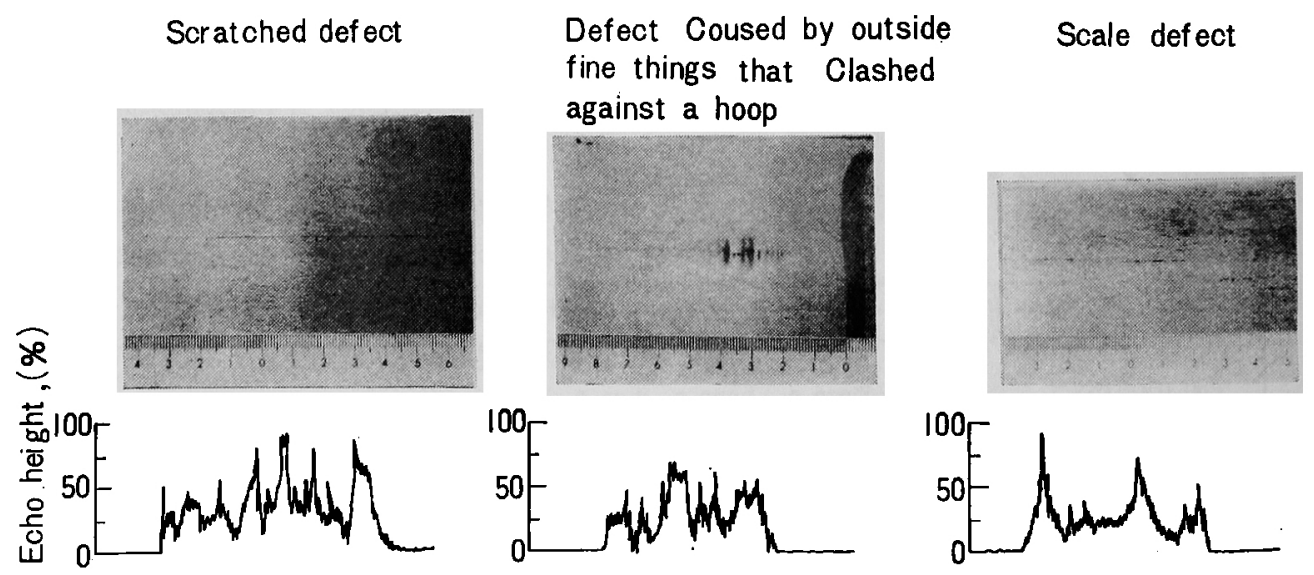

Fig. 10. Test results of continuous detecting for natural defects. 


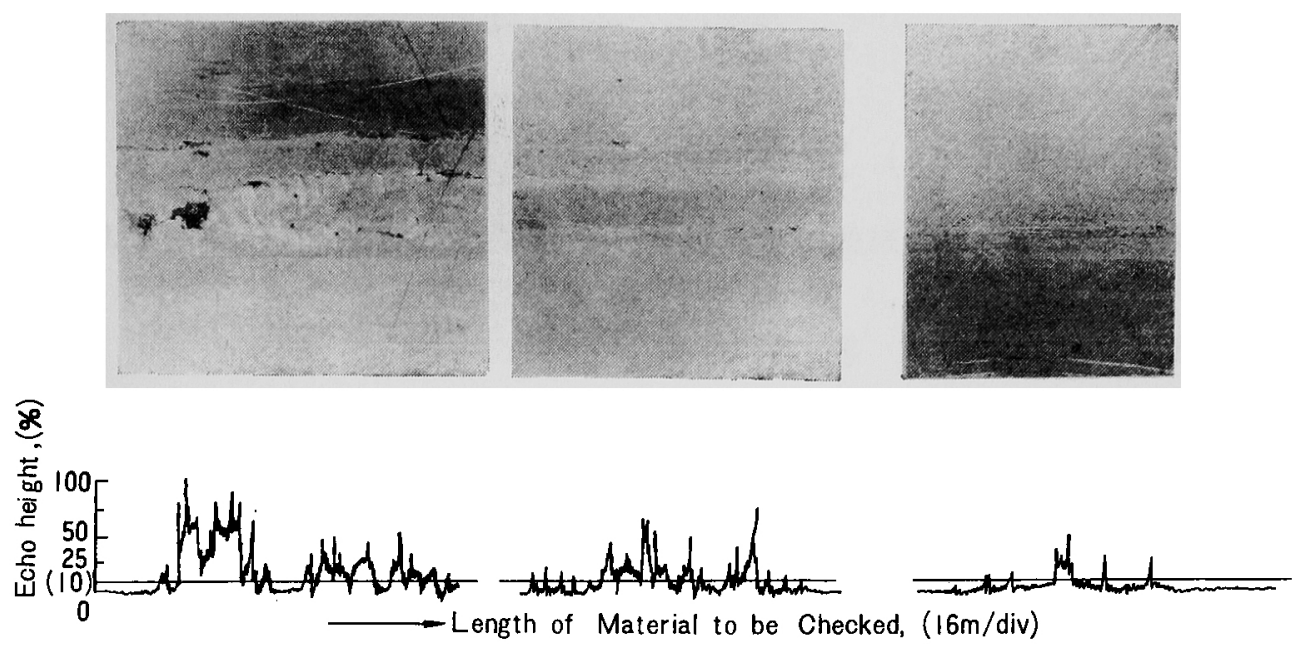

Fig.11. Test results of detecting for some peeled off defects. I .
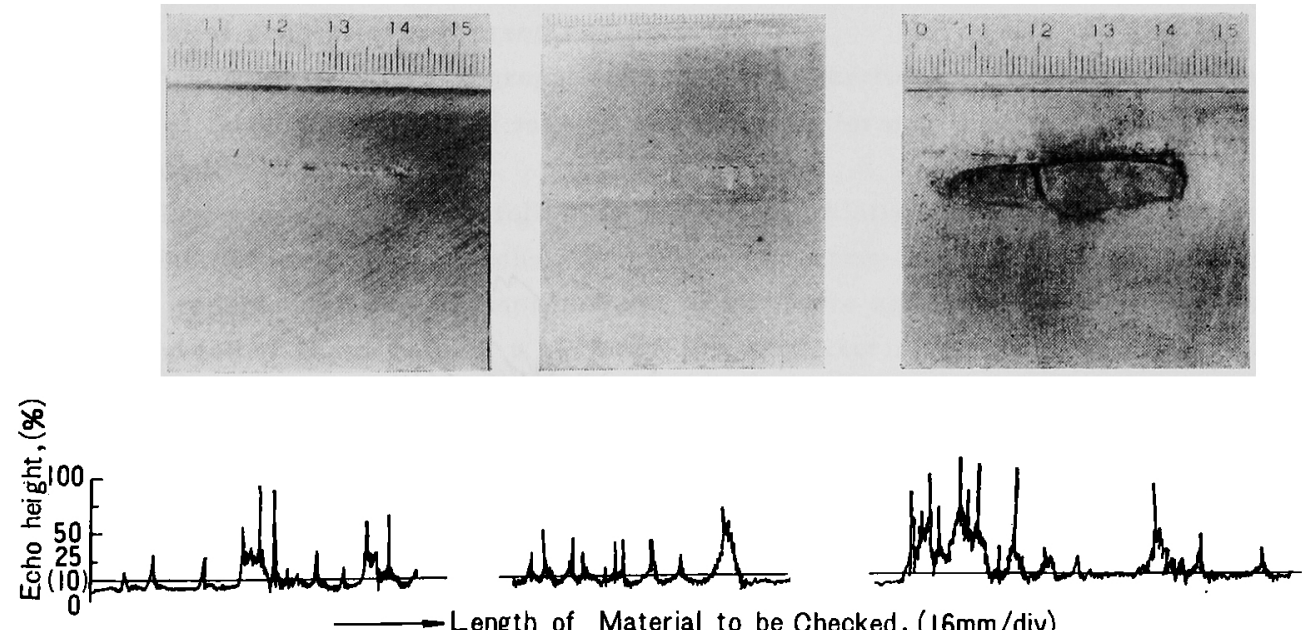

Length of Material to be Checked, ( $16 \mathrm{~mm} /$ div)

Fig.12. Test results of detecting for some peeled off defects. II 


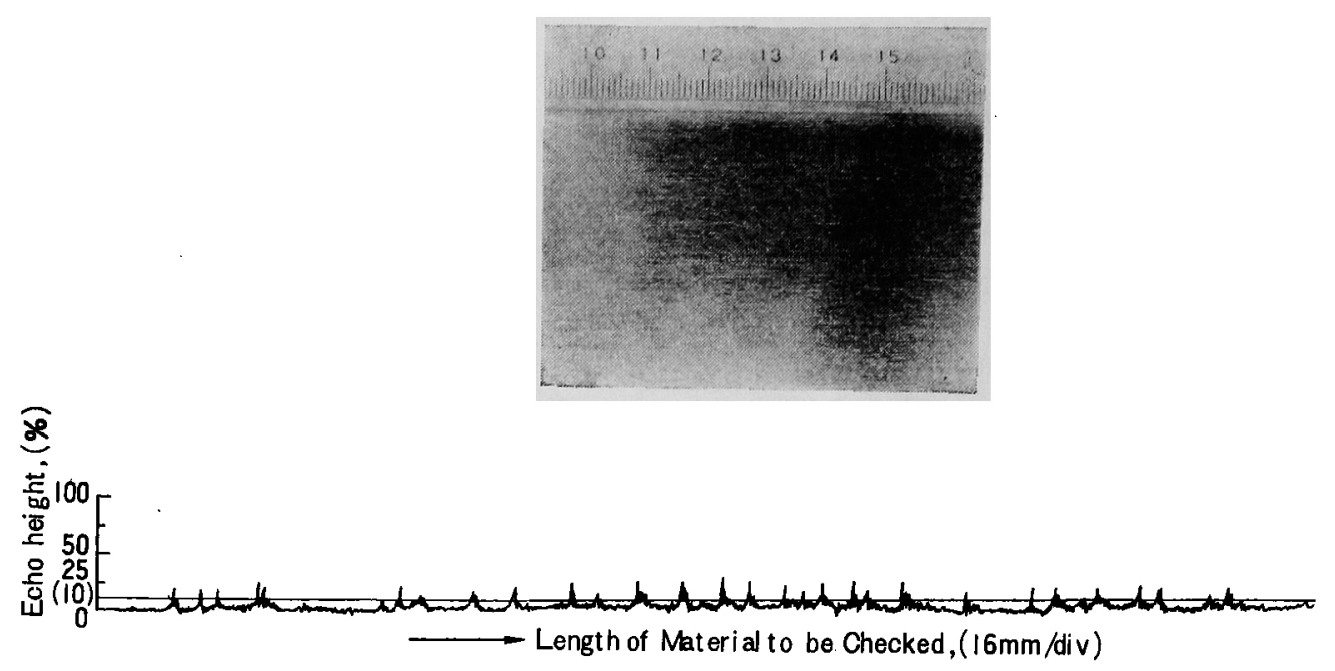

Fig. 13. Test results of detecting for rough skin.

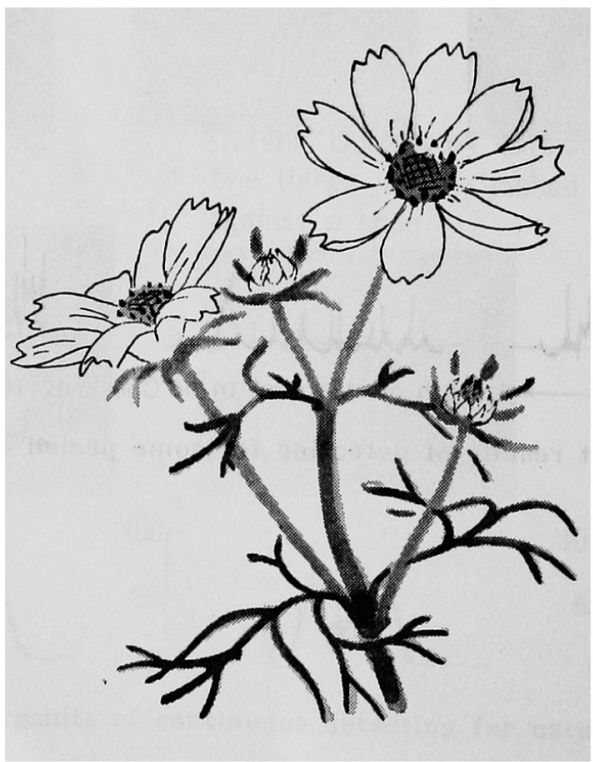

